\title{
RESEARCH EXAMINATION OF THE OPTIONS TO INCREASE THE EDUCATION EFFECTIVENESS IN THE TECHNICAL SUBJECTS AT THE 2. LEVEL OF PRIMARY SCHOOL USING HYPERTEXT EDUCATIONAL MATERIAL
}

\author{
Lubomír ŽÁČOK
}

\begin{abstract}
The teacher as the activator of the process of education, he can control and teach the pupils using technical data, though he must be able to have own reflexion and evaluation for himself. He supports individual, but kooperative work of pupils as well, he keeps pedagogical, psychological and social aspects at the education. He uses appropriate educational stuff and the didactical technics. The new medias and various innovative excercises are motivating elements from the subject of the technics and the new technologies. Our aim is to propose the system of controlled study for pupils using didactical environment created by hypertext portal. Important parts of this project are to find out the method how to create mentioned environment and also its following application by the teachers at the education of technical subjects. The effectiveness of this new method will be examined by a pedagogical experiment.
\end{abstract}

Key words: hypertext, research, pedagogical experiment.

\section{VÝSKUM MOŽNOSTI ZVYŠOVANIA EFEKTÍVNOSTI VYUČOVANIA TECHNICKÝCH PREDMETOV NA 2. STUPNI ZÁKLADNEJ ŠKOLY POMOCOU HYPERTEXTOVÝCH UČEBNÝCH MATERIÁLOV}

Kl'účové slová: hypertext, výskum, pedagogický experiment.

Resumé: Učitel ako aktivátor výchovno-vzdelávacieho procesu riadi a približuje odborné fakty žiakom, avšak musí byt' schopný sebareflexie a evalvácie. Podporuje samostatnú, ale pritom kooperatívnu prácu žiakov, dodržiava pedagogické, psychologické a sociálne aspekty pri vzdelávaní. Použiva primerané učebné pomôcky a didaktickú techniku. Motivačnými elementmi sú nové médiá a rôzne inovatívne úlohy z techniky a nových technológií. Našim cielom bolo navrhnút' systém riadeného štúdia využivajúceho didaktické prostredie vytvorené hypertextovým portálom. Účinnost' novokoncipovaného postupu bola overená pedagogickým experimentom.

\section{Súčasný stav problematiky}

Problematika modernizácie všeobecného vzdelania z hladiska začlenenia učiva technologického charakteru do jeho obsahu je jedným z nosných programov, ktoré rieši aj UNESCO. Zavedenie vyučovania predmetov technického charakteru umožňuje poznat' určité konkrétne formy práce, no predovšetkým rozvíja technické myslenie a technickú tvorivost' u žiakov už počas školskej dochádzky. Technické predmety (Technika a Technická výchova) v sústave vyučovacích predmetov na II. stupni základnej školy majú zabezpečené základné definičné podmienky samostatného vyučovacieho predmetu - majú vymedzený predmet, vyučovacie metódy, terminologický i didaktický systém. Techniku a Technickú výchovu možno považovat' za rozhodujúci činitel' prípravy na život $v$ technosfére. UNESCO Pilot Projekt vytýčil úlohu zaradit' poznatky $\mathrm{z}$ techniky do obsahu všeobecného vzdelania. Zoznámenie žiakov s technickými poznatkami a osvojenie základných pracovných zručností a návykov riešili jednotlivé krajiny $v$ súlade $\mathrm{s}$ týmto projektom $\mathrm{v}$ podstate $\mathrm{v}$ dvoch rovinách, a to:

- Zavedením špeciálneho predmetu technického charakteru (technology).

- Zarad'ovaním tematických celkov technickej povahy do učebných osnov nosných predmetov prírodných vied.

Projekt zdôrazňoval a zdôrazňuje nutnost' udržiavat' tempo so zmenami vo výrobe, čo vyžaduje prípravu mladej generácie dostatočne flexibilnú a adaptabilnú pre rýchlo sa meniace podmienky voblasti techniky $\mathrm{v}$ súčasnosti i v budúcnosti.

Aj u nás sa na dosiahnutie určitej základnej úrovne technického vzdelania musí podiel'at' 
i základná škola, ktorá v systéme vyučovacích predmetov má zaradený i vyučovací predmet Technika (podl'a nového Štátneho vzdelávacieho programu) a Technická výchova. Dané predmety majú svoje pevné a nezastupitel'né miesto v sekundárnom vzdelávaní. V týchto predmetoch, sa vychádza predovšetkým z princípu spojenia školy so životom. Technické vzdelávanie musí byt' organickou súčast'ou všeobecného vzdelávania na všetkých stupňoch škôl. Človek s tvorivým technickým myslením má väčšiu šancu uplatnit' sa v súčasnej technicky zmodernizovanej spoločnosti. Pod tvorivým technickým myslením rozumieme aktívne riešenie problémov a nachádzanie viacerých možností riešenia problémov. Tvorivé technické myslenie je divergentným procesom, ktorý smeruje od prijímania poznatkov cez ich reorganizáciu $\mathrm{k}$ tvorbe nového poznatku. Pod zmodernizovanou spoločnost'ou rozumieme spoločnost', od ktorej sa v súčasnosti vyžaduje aktívna práca s informačnými a komunikačnými technológiami, kde môžeme zaradit' aj hypertextové učebné materiály. Vedomosti z tejto oblasti je možné nadobudnút' už v základnej škole v predmete Technika a Technická výchova. Takto človek dokáže l'ahšie pochopit' princíp činnosti rôznych technických zariadení. A práve táto gramotnost' musí tvorit' základ súčasného moderného vzdelávania. Pod technickou gramotnost'ou rozumieme technicky vzdelanostné minimum, ktoré by si mal v rámci všeobecného vzdelávania osvojit' každý l'udský jedinec.

Súčasná škola musí mladému človeku umožnit' získanie základnej technickej gramotnosti. Je potrebné si uvedomit', že žijeme $\mathrm{v}$ dobe, $\mathrm{v}$ ktorej technika musí svoje pevné miesto posilňovat' nielen $\mathrm{v}$ praxi, ale i v súčasnej škole. Je potrebné si uvedomit', že každý človek nie je producentom technických objektov, ale jeho používatel'om.

\section{Predpokladaný vlastný prínos}

Obsah učiva je obohacovaný o informácie súvisiace so vzt’ahom človeka $\mathrm{k}$ práci, $\mathrm{s}$ potrebou osvojit' si základné pracovné zručnosti a návyky $\mathrm{v}$ rôznych pracovných oblastiach. Vzdelávanie $\mathrm{v}$ tejto oblasti smeruje $\mathrm{k}$ vytváraniu a rozvíjaniu kl'účových kompetencií žiakov tým, že vedie žiakov k objektívnemu poznávaniu okolitého sveta, $\mathrm{k}$ potrebnej sebadôvere, $\mathrm{k}$ novému postoju a hodnotám vo vzt’ahu k práci človeka, technike a životnému prostrediu. Ciele technického vzdelávania v základnej škole zahŕňajú oblast' kognitívnu, afektívnu a psychomotorickú, ktoré je potrebné proporcionálne rozvíjat'. Ciele sú zostavené $\mathrm{v}$ zmysle týchto kl'účových kompetencií:

- dokázat' uplatnit' získané znalosti a spôsobilosti $\mathrm{v}$ rozličných pracovných a mimopracovných životných situáciách,

- navrhovat' nové úlohy, nové riešenia, vyhl'adávat' riešenia úloh $\mathrm{v}$ nových projektoch,

schopnost' plánovat' a riadit' prácu.

Učitel' výchovno-vzdelávacieho procesu riadi a približuje technické a odborné fakty žiakom. Používa na dosiahnutie ciel'a primerané učebné pomôcky tradičné i najmodernejšie podl'a potreby. Medzi modernejšie a novšie učebné pomôcky môžeme zaradit' multimediálne učebné pomôcky, ktoré spájajú rôzne druhy informácií. Medzi charakteristické znaky multimédií zarad'ujeme aj hypertext. Textové informácie sme si donedávna vedeli predstavit' iba $\mathrm{v}$ ich klasickej podobe $\mathrm{v}$ časopisoch, novinách alebo $\mathrm{v}$ učebnici. Klasický text má jednoduchú lineárnu štruktúru. Nové možnosti využitia počítačov umožňujú vytvorenie novej podoby textu, kde lineárny text je iba východiskovou jednotkou široko rozvetvenej štruktúry označovanej ako hypertext. $\mathrm{Z}$ informačného hl'adiska definujeme hypertext ako množinu textových informácií. Prvkami tejto množiny sú informačné jednotky (information items). Informačné jednotky sú medzi sebou prepojené do lineárnej, stromovej, siet'ovej, pavučinovej, príp. inej štruktúry pomocou hyperliniek. Z týchto informačných jednotiek sa na základe určitých pravidiel zostavujú informačné celky. Väzby medzi jednotlivými informačnými celkami umožňujú efektívny prístup $\mathrm{k}$ informáciám. Technické a programové prostriedky, ktoré umožňujú uchovávat' tieto informácie vo forme hypertextu (teda tvorit' hypertext) a umožňujú efektívny a pohodlný prístup $\mathrm{k}$ týmto informáciám (teda využívat' hypertext), označujeme ako hypertextový systém. Vlastnost'ou hypertextu je spájat' je spájat' text. Pri práci s hypertextom môžeme využit' jeho d'alšie možnosti. Hypertext umožňuje jeho čitatel'ovi návrat na predchádzajúce alebo naopak posun na nasledujúce strany za predpokladu, že s danými stranami už pracoval, ponuku už zobrazených strán, ktoré navštívil a iné. Tieto vlastnosti a štruktúru hypertextu využívajú niektoré výučbové softvéry, multimediálne encyklopédie a nakoniec typickým príkladom hypertextu je služba World Wide Web. 
Zdravá sútaživost' medzi žiakmi je prirodzená, ale medzi skupinami žiakov musí existovat spolupatričnost', zodpovednost' a tímový duch. Tvorbou hypertextových učebných materiálov pre technické predmety je možné povzbudit záujem žiakov vzdelávat' sa. Je možné využit' aj princíp dramatizácie na zvýšenie aktivity žiakov, aby sa mohli priamo podiel'at' na vzdelávaní. Rozširovanie pedagogického pôsobenia učitel'ov prostredníctvom hypertextových učebných materiálov vidíme $\mathrm{v}$ efektívnom transferi nových vedeckých poznatkov $\mathrm{v}$ rámci rýchle sa rozvíjajúcich technických disciplín, ktoré tvoria podstatu tzv. technickej revolúcie.

3 Ciele a obsah tematických celkov $v 7$. ročníku v predmete Technická výchova

Do obsahu predmetu Technická výchova $\mathrm{v} 7$. ročníku základnej školy patria nasledujúce tematické celky:

- Operácie a nástroje na spracovanie technických materiálov,

- Mechanizačné prostriedky,

- Prvky bytovej inštalácie,

口 Elektromontážne práce. Elektronické automatizačné a regulačné prvky,

๑ Samostatná práca žiakov.

Pod obsahom učiva rozumieme učivo, ktoré sa má žiak naučit' v škole. Je to súhrn vedomostí, zručností a návykov, ktorých osvojenie zabezpečuje rozvoj duševných a fyzických schopností žiakov potrebných pre ich d'alší život.

Dalej sa pokúsime analyzovat' jednotlivé tematické celky a poukázat' na nedostatky novej učebnice, $\mathrm{v}$ ktorej sa nachádza príslušné učivo. Jednou z prvých tém v 7. ročníku základnej školy je tematický celok „Zložitejšie operácie a nástroje na spracovanie technických materiálov“. V tematickom celku „Operácie a nástroje na spracovanie technických materiálov" učitel' rozvíja technické myslenie a predstavivost' žiakov. Obsah tematického celku je zameraný tak, aby sa $\mathrm{V}$ ňom žiaci bližšie oboznámili s technickými materiálmi, vedeli ich ručne obrábat' a spracovávat' prostredníctvom základných. technických operácii a s využitím dostupného a primeraného náradia, nástrojov a pomôcok. Žiaci by mali pochopit', vediet' a oboznámit' sa s vlastnost'ami a vhodným výberom technických materiálov. Požiadavky na vedomosti a zručnosti $\mathrm{v}$ tomto tematickom celku by mali obsahovat': hobl'ovanie, dlabanie, vítanie, spájanie technických materiálov rozoberatel'né a nerozoberatel'né - čapovaním, lepením, klincami, skrutkami, nitovaním, spájkovaním, zváraním, princíp odlievania, vonkajšie a vnútorné závity - ručné rezanie. Vymenovat' vlastnosti a využitie doskových výrobkov $\mathrm{z}$ dreva, profilových kovových polotovarov a plastov. Tieto materiály vediet' rezat', pilovat', brúsit'. Vediet' vybrat' vhodný materiál na základe poznania jeho mechanických a fyzikálnych vlastností. Prakticky vediet' spájat' drevo klincami, skrutkami, lepením, plátovaním. Poznat' a vediet' opísat' spájanie dreva kolíkmi a čapovaním. Poznat' základy ručného a strojového obrábania dreva, kovov a plastov. Oboznámit' sa s hobl'ovaním dreva, poznat' základné časti hoblíka a druhy hoblíkov.

Vediet' spájkovat', vediet' určit' skrutkové a maticové spoje, oboznámit' sa s nitovaním.

Poznat princíp odlievania kovov (plastov) a zhotovenia odliatkov. Vediet' rozlíšit' a popísat' rozoberatel'né a nerozoberatel'né spájanie dreva, kovov a plastov (klincami, skrutkami, skrutkami a maticami, lepením, spájkovaním, zváraním, konštrukčným spájaním, nitovaním). Oboznámit' sa $\mathrm{s}$ podstatou a rozdielom medzi spájaním kovov, spájkovaním a zváraním. Prakticky si osvojit' dlabanie dreva, vŕtanie kolovrátkom a ručnou vítačkou. Vediet' merat' posuvným meradlom. Poznat' teoreticky i prakticky postup pri rezaní vonkajších a vnútorných závitov. Prakticky zhotovit' spoj spájkovaním. Vediet' opísat' a zhotovit' spoj dreva čapovaním. Oboznámit' sa postupom zhotovenia jednoduchej formy na odlievanie predmetov z vosku. Učivo je vhodné prebrat' súbežne $\mathrm{s}$ výrobou jednoduchých výrobkov, napríklad výrobok bude zhotovený kombináciou drevo, plast, kov. Ked’že sa vychádza z podmienok danej školy, je možné realizovat' výrobky len z materiálu, ktorý má učitel' $\mathrm{k}$ dispozícií ( napr. len drevo, plast, alebo len kov, poprípade iné dostupné prírodné materiály, napr. koža). Pritom na základe vedy a techniky kontinuálne dopĺn̆a dané učivo o nové informácie. Vedie žiakov k osvojovaniu učiva tak, aby používali a osvojili si správnu technickú odbornú terminológiu. Oboznamuje žiakov $\mathrm{s}$ bezpečnost'ou a hygienou pri práci. $\mathrm{V}$ tomto tematickom celku je dôraz kladený na správne upevnenie materiálu, držanie a vedenie nástroja a na správny postoj pri práci, koordináciu rúk, nôh, rýchlost' pohybov s nástrojom, ako i na smer jeho vedenia. Učitel' pri praktickej činnosti žiakov sleduje tieto zásady, žiakov usmerňuje a upozorňuje na chyby, ktorých sa dopúštajú.

Obsah tematického celku „Princíp práce a mechanické prvky mechanizačných 
prostriedkov v domácnosti“" je zameraný na mechanizačné prostriedky a prostriedky malej ručnej mechanizácie, ktoré tvoria hlavný obsah tohto tematického celku. Obsah je zameraný na ich hlavné rozdelenie, použitie, ich význam pre človeka a bezpečnost' pri práci s nimi. Žiaci sa naučia hospodárne a racionálne používat' mechanizačné prostriedky v domácnosti. Spoznajú zásady bezpečnej práce s nimi a ich bežnej údržby. Ručné a elektrické mechanizmy v domácnosti a v školskej dielenskej učebni, ich funkcia, činnost', obsluha, používanie, údržba. Zásady bezpečnej obsluhy a práce s ručnými a elektrickými mechanizačnými prostriedkami. Požiadavky na vedomosti a zručnosti žiakov v tomto tematickom celku sú: Oboznámit' sa s princípom a poznat' účel najfrekventovanejších domácich ručných a elektrických mechanizmov (kuchynské a záhradné, ručné a motorové). Vediet' obsluhovat' nenáročné základné domáce mechanizmy a vykonávat' základné práce pri ich údržbe. Vediet' vysvetlit' funkciu malej ručnej mechanizácie, s ktorou sa žiaci môžu stretnút' na technickej výchove (vŕtačka, elektrická brúska, pásová, kmitavá a kotúčová píla, striekacia pištol'). Poznat' zásady bezpečnej práce s ručnými a elektrickými mechanizačnými prostriedkami v domácnosti a na technickej výchove. Vediet' vykonávat' prakticky bežnú údržbu niektorých druhov domácich mechanizmov (vysávač, chladnička, odšt'avovač a pod.) Oboznámit' sa so zaobchádzaním a prácou $\mathrm{s}$ prostriedkami malej ručnej mechanizácie a bezpečnost’ou pri práci s nimi (ručná vŕtačka, brúska na kov, okružná píla, kmitavá píla, atd'.). Výrazný didaktický účinok môže učitel' docielit' i praktickou ukážkou na vyučovacej hodine (pre praktickú ukážku je vhodný i nefunkčný spotrebič). Tu učitel'ovi efektívne pomôže publikácia Spotrebiče v domácnosti (Ďuriš a Pavlovkin, 2003), ktorá vyšla na Fakulte prírodných vied UMB v Banskej Bystrici v prvom polroku 2003. V texte publikácie autori prezentujú výber najčastejšie používaných spotrebičov v domácnosti, ktoré sú podl'a princípu činnosti rozdelené na spotrebiče elektrické a mechanické. Pri každom spotrebiči je zachovaná rovnaká štruktúra. Vychádza sa z konštrukcie spotrebiča, pričom je dôraz kladený na princíp jeho činnosti, základnú údržbu a jeho prípadnú opravu. Text je doplnený schémami i obrázkami tak, aby používatel' mal v jednoduchej podobe čo najširšiu informáciu. Do textu sú štylisticky zaradené i otázky a úlohy určené k upevneniu a zopakovaniu daného učiva. Súčast'ou publikácie je i CD ROM, na ktorom používatel' nájde separátne všetky obrázky, s ktorými sa stretáva v texte ( Duriš a Pavlovkin, 2003).

Obsah tematického celku , Základné prvky bytovej inštalácie " žiakom približuje základné informácie $\mathrm{z}$ oblasti bytovej inštalácie. V tomto novozavedenom tematickom celku je obsah učiva zameraný na základné informácie $\mathrm{v}$ oblasti bytovej inštalácie - kúrenie, rozvod studenej a teplej vody, celkove na domácnost' a úsporu energie, ekologické aspekty a malú údržbu v domácnosti. Žiaci sa oboznámia so systémom, základmi konštrukcie a údržby jednotlivých prvkov bytovej inštalácie. Naučia sa ekonomicky a ekologicky hodnotit' jednotlivé systémy.

Žiaci sa oboznamujú so systémom ústredného kúrenia $\mathrm{v}$ bytoch a jeho funkciou. Vediet' popísat' systém rozvodu studenej a teplej vody $\mathrm{v}$ byte. Poznajú zloženie a funkciu vodovodného kohútika a jednoduchej vodovodnej batérie. Oboznámit' sa s praktickou výmenou tesnenia alebo vložky vo vodovodnom kohútiku (v batérii) a s opravou splachovača WC. Poznajú možnosti šetrenia teplom a teplou vodou a zároveň spôsoby zamedzenia úniku tepla - spôsoby zateplenia okien a dverí. Vedia popísat' princíp spal'ovania vo vykurovacích zariadeniach - ústredného kúrenia. Oboznamujú sa so schémou ústredného kúrenia a základnou konštrukciou kotla. Vedia vypočítat' spotrebu energie na kúrenie. Prakticky si osvojit' opravu netesnosti vodovodného kohútika (batérie) výmenou tesnenia, frézovaním sediel alebo výmenou vložiek ventilov. Učitel' čerpá poznatky $\mathrm{z}$ učebnice pre vyučovanie technickej výchovy. Vhodná je aj už spomenutá publikácia Spotrebiče v domácnosti (Ďuriš a Pavlovkin, 2003). Pritom na základe vedy a techniky kontinuálne dopíňa dané učivo o nové informácie.

Obsah tematického celku , Elektromontážne práce. Elektronické automatizačné a regulačné prvky" prakticky rozširuje a prehlbuje vedomosti a zručnosti žiakov pri elektromontážnych prácach. Podstatnú čast' tvorí praktické precvičenie spájkovania pri zapájaní elektrických obvodov. Žiaci sa oboznámia s prvkami automatizácie a upevnia si návyky bezpečnej práce s elektrickým prúdom.

Poznajú základné prvky automatizácie a ich uplatnenie $\mathrm{v}$ domácich elektrických spotrebičoch (elektrický zvonček, elektromagnetické relé, bimetalový regulátor teploty, regulačný ventil, rôzne druhy snímačov). Vedia nakreslit' elektrickú schému a správne zapojit' obvod elektrického zvončeka. Vedia popísat' systém 
domovej elektrickej inštalácie a najdôležitejšie súčasti inštalačného obvodu. Oboznámujú sa $\mathrm{s}$ indikáciou napätia $\mathrm{v}$ elektrickom obvode.. Vedia vysvetlit' význam automatizácie výroby pre človeka a výrobu. Poznajú princíp elektromagnetického relé a základné obvody s jeho uplatnením. Poznajú princíp práce automatického vypínača - ističa. Vedia vysvetlit' niektoré automatické systémy - V žehličke, automatické otváranie dverí, osvetlenie, tlačiarne PC, princíp činnosti výtahu a pod. Poznajú princíp práce disku (HDD, FDD) V počítači. Oboznamujú sa s hardvérom a softvérom PC.

Posledným tematickým celkom, ktorý je určený učebnými osnovami $\mathrm{v} 7$. ročníku v predmete Technická výchova je „Samostatná práca žiakov". V tomto tematickom celku majú žiaci získané teoretické vedomosti a praktické zručnosti čo najlepšie uplatnit'. Úlohou v tomto tematickom celku je, aby žiaci samostatne a správne načrtli konštrukciu zvoleného námetu, vybrali správny materiál, postupovali podla správneho technologického postupu, prípadne zvolili vhodnú povrchovú úpravu. Po dôkladnom zoznámení sa s pracovným postupom zhotovenia výrobku a rozdaní materiálu, žiaci pracujú individuálne alebo v skupinách. Učitel' ich činnost' usmerňuje diskusiou individuálne alebo frontálne. Ciel'om tohto tematického celku je rozvíjanie samostatnosti a tvorivosti žiakov prostredníctvom návrhu, resp. výberu a zhotovenia vybratých výrobkov s uplatnením riešenia vhodných technických problémov. Zhotovenie zvolených pracovných námetov s úlohami typu:

口 vol'ba konštrukcie (elaborácia), dokončenie ideového námetu, prípadne zmenou

口 konštrukcie,

口 vol'ba materiálu,

- vol'ba technologického postupu,

口 vol'ba povrchovej úpravy a pod.

Výrobky môžu byt' z kovu, dreva, plastov, alebo kombinované, prípadne v kombinácii s elektroinštaláciou. Spolupráca pri opravách a údržbe inštalačného zariadenia v škole.

\section{Metodika a organizácia výskumu}

Použili sme pedagogický experiment, ako výskumnú metódu. Stratégia výskumu bola podmienená charakterom problému, ktorý v práci riešime a tým je návrh, tvorba a overenie hypertextového učebného textu v edukačnom procese. $\mathrm{Na}$ skúmanie výkonov žiakov v kognitívnej oblasti sme použili neštandardizovaný kognitívny výstupný didaktický test. Didaktický test bol rozlišujúci, čiže výkony žiakov kontrolnej skupiny sa porovnávali s výkonmi žiakov experimentálnej skupiny. Získané údaje sme spracovali pomocou základných štatistických metód. Vypočítali sme základné štatistické charakteristiky (aritmetický priemer, smerodajnú odchýlku a chybu, medián, modus a pod.). Následne sme testovali stanovené hypotézy na hladine významnosti $\alpha=0,05$.

\section{Pedagogický experiment}

Zaoberali sme sa problémom, do akej miery existujúci hypertextový učebný text pomôže žiakom 7. ročníka, respektíve bude mat' vplyv na stupeň dosiahnutých osvojených vedomosti. V kontrolnej skupine (K) prebiehala výučba tradičným spôsobom (žiaci nepracovali s hypertextovým učebným textom) a v experimentálnej skupine (E) žiaci pracovali s hypertextovým učebným textom. Po skončení výučby v kontrolnej a experimentálnej skupine sme použili didaktický test pre obidve skupiny na konci prirodzeného pedagogického experimentu. Didaktický test (DT) bol určený pre žiakov 7. ročníka základnej školy.

\section{Stanovenie hypotéz}

$\boldsymbol{H}_{0}$ : Výsledky dosiahnuté pomocou neštandardizovaného didaktického testu $v$ kontrolnej a experimentálnej skupine budú rovnaké

$\boldsymbol{H}_{1}$ : Predpokladáme, že hypertextový učebný text zvýši efektívnost' vyučovania technickej výchovy v 7. ročníku základnej školy.

$\boldsymbol{H}_{2}$ : Respondenti experimentálnej skupiny dosiahnu pri výučbe s hypertextovým učebným textom vyšši výkon v kognitívnej oblasti $v$ porovnani skontrolnou skupinou, kde bude výučba realizovaná tradičnými metódami, bez použitia hypertextového učebného textu.

$\boldsymbol{H}_{2.1}$ : Predpokladáme, že žiaci experimentálnej skupiny dosiahnu pri výučbe s s hypertextovým učebným textom vyšši výkon vúrovni učenia „,zapamätanie“ v porovnaní so žiakmi kontrolnej skupiny, kde bude výučba realizovaná bez použitia hypertextového učebného textu .

$\boldsymbol{H}_{2.2}$ : Predpokladáme, že žiaci experimentálnej skupiny dosiahnu pri výučbe spracovnými zošitmi vyšši výkon vúrovni učenia „porozumenie“ v porovnaní so žiakmi kontrolnej skupiny, kde bude výučba realizovaná bez použitia hypertextového učebného textu.

$\boldsymbol{H}_{2.3}$ : Predpokladáme, že žiaci experimentálnej skupiny dosiahnu pri výučbe s hypertextovým 
učebným textom vyšši výkon vúrovni učenia „špecifický transfer" v porovnaní so žiakmi kontrolnej skupiny, kde bude výučba realizovaná bez použitia hypertextového učebného textu.

$\boldsymbol{H}_{2.4}$ : Predpokladáme, že žiaci experimentálnej skupiny dosiahnu pri výučbe shypertextovým učebným textom vyšši výkon vúrovni učenia „,nešpecifický transfer" v porovnaní so žiakmi kontrolnej skupiny, kde bude výučba realizovaná bez použitia hypertextového učebného textu.

\section{Výberová vzorka výskumu}

Výskumnú vzorku tvorili žiaci 7. ročníka základných škôl. Vo výskume bolo zahrnutých 12 kontrolných skupín v počte žiakov 300 a 12 7 Štatistická verifikácia hypotéz výskumu experimentálnych skupín v počte 300 žiakov. Kontrolné a experimentálne skupiny predstavovali vzorku s počtom žiakov 600 . V základnom súbore bolo 15 škôl $\mathrm{z}$ celej Slovenskej republiky. Náhodným výberom (žrebovaním) sme vybrali 12 škôl. Z každej školy sme vybrali náhodným výberom 50 žiakov, ktorí boli žrebovaním rozdelení do dvoch skupín experimentálnej a kontrolnej. Kontrolné a experimentálne skupiny boli rovnocenné v ukazovatel'och počtu žiakov a pohlavia žiakov. Pedagogický experiment bol realizovaný $\mathrm{v} 7$. ročníku základnej školy a žiadny zo žiakov neopakoval ročník a probanti boli vekom takmer totožní.

Tabul'ka 1: Základné štatistické charakteristiky.

\begin{tabular}{|l|r|r|r|c|c|r|r|}
\hline & & & \multicolumn{1}{c|}{ skóre } & skóre & \multicolumn{1}{c|}{ skóre } & \multicolumn{1}{c|}{ skóre } & \multicolumn{1}{c|}{ skóre } \\
\hline & Level of Factor & $\mathrm{N}$ & \multicolumn{1}{c|}{ Mean } & Std.Dev. & Std.Err. & \multicolumn{1}{c|}{$-95 \%$} & \multicolumn{1}{c|}{$95 \%$} \\
\hline Total & & 600 & 10,60167 & 3,558431 & 0,145272 & 10,31636 & 10,88697 \\
\hline skupina & kontrolná & 300 & 9,56333 & 3,500022 & 0,202074 & 9,16567 & 9,96100 \\
\hline skupina & experimentálna & 300 & 11,64000 & 3,309619 & 0,191081 & 11,26397 & 12,01603 \\
\hline
\end{tabular}

Tabul'ka 2 a 3: Základné štatistické charakteristiky.

\begin{tabular}{|l|r|l|l|l|l|}
\hline Variables & A & kontrolná & Variables & A & Exper. \\
\hline Valid data & 300 & & Valid data & 300 & \\
\hline Missing data & 0 & & Missing data & 0 & \\
\hline Sum & 2869 & & Sum & 3492 & \\
\hline Mean & 9,563333 & & Mean & 11,64 & \\
\hline Variance & 12,25016 & & Variance & 10,95358 & \\
\hline Standard deviation & 3,500022 & & Standard deviation & 3,309619 & \\
\hline Variance coefficient & 0,365984 & & Variance coefficient & 0,284332 & \\
\hline $\begin{array}{l}\text { Standard error of } \\
\text { mean }\end{array}$ & 0,202074 & & $\begin{array}{l}\text { Standard error of } \\
\text { mean }\end{array}$ & 0,191081 & \\
\hline $\begin{array}{l}\text { Upper 95\% CL of } \\
\text { mean }\end{array}$ & 9,961001 & & $\begin{array}{l}\text { Upper 95\% CL of } \\
\text { mean }\end{array}$ & 12,01603 & \\
\hline $\begin{array}{l}\text { Lower 95\% CL of } \\
\text { mean }\end{array}$ & 9,165666 & & $\begin{array}{l}\text { Lower 95\% CL of } \\
\text { mean }\end{array}$ & 11,26397 & \\
\hline Geometric mean & 8,805213 & & Geometric mean & 11,01388 & \\
\hline Skewness & $-0,2624$ & & Skewness & $-0,92298$ & \\
\hline Kurtosis & 1,743843 & & Kurtosis & 2,721242 & \\
\hline Maximum & 15 & & Maximum & 15 & \\
\hline Upper quartile & 12,5 & & Upper quartile & 14 & \\
\hline Median & 11 & & Median & 12,5 & \\
\hline Lower quartile & 6 & & Lower quartile & 10,5 & \\
\hline Minimum & 3,5 & & Minimum & 4,5 & \\
\hline Range & 11,5 & & Range & 10,5 & \\
\hline Centile 95 & 14,5 & & Centile 95 & 15 & \\
\hline Centile 5 & 3,5 & & Centile 5 & 4,5 & \\
\hline
\end{tabular}




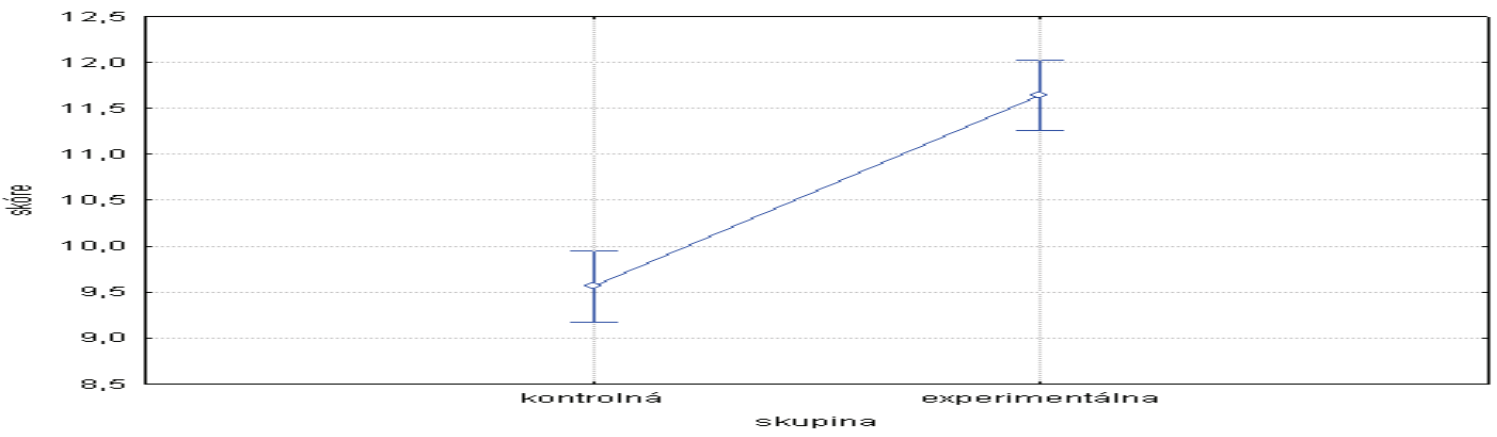

Graf 1: Porovnanie výsledkov dosiahnutých v kontrolnej a experimentálnej skupine v 7. ročníku.

Tabul'ka 4: Kruskal - Wallis test.

\begin{tabular}{|c|c|c|c|c|}
\hline & kontrolná & experimentálna & Total & \\
\hline$<=$ Median: observed & 191,0000 & 122,0000 & 313,0000 & \\
\hline expected & 156,5000 & 156,5000 & & \\
\hline obs.-exp. & 34,5000 & $-34,5000$ & & \\
\hline > Median: observed & 109,0000 & 178,0000 & 287,0000 & \\
\hline expected & 143,5000 & 143,5000 & & \\
\hline obs.-exp. & $-34,5000$ & 34,5000 & & \\
\hline Total: observed & 300,0000 & 300,0000 & 600,0000 & \\
\hline & $\begin{array}{l}\text { Overall } \\
\text { Median }\end{array}$ & df & $\begin{array}{l}\text { Chi- } \\
\text { Square }\end{array}$ & $\mathrm{p}$ \\
\hline Median test & 11,5 & 1 & 31,79971 & 0,0000 \\
\hline & Valid & Sum of Ranks & & \\
\hline kontrolná & 300 & 73980,0 & & \\
\hline experimentálna & 300 & 106320,0 & & \\
\hline & $\mathrm{N}$ & df & $\mathrm{H}$ & $\mathrm{p}$ \\
\hline Kruskal-Wallis test & 600 & 1 & 58,34968 & 0,0000 \\
\hline
\end{tabular}

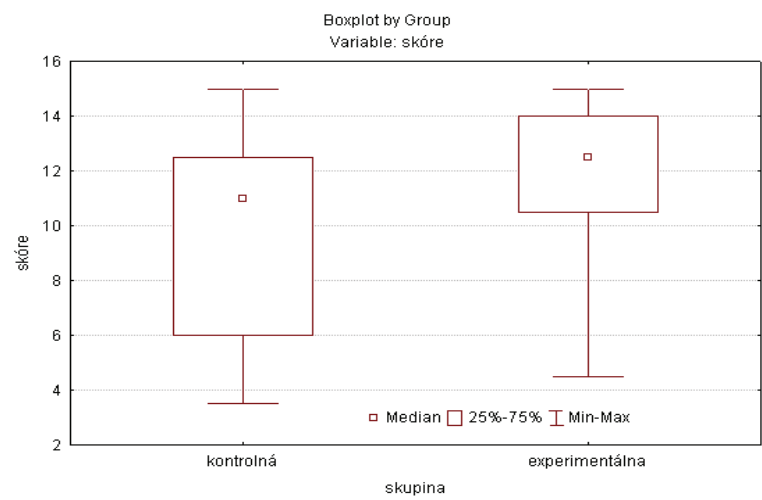

Graf 2: Medián, kvartilové a variačné rozpätie premenných $z$ výstupného testu $v$ 7. ročníku.

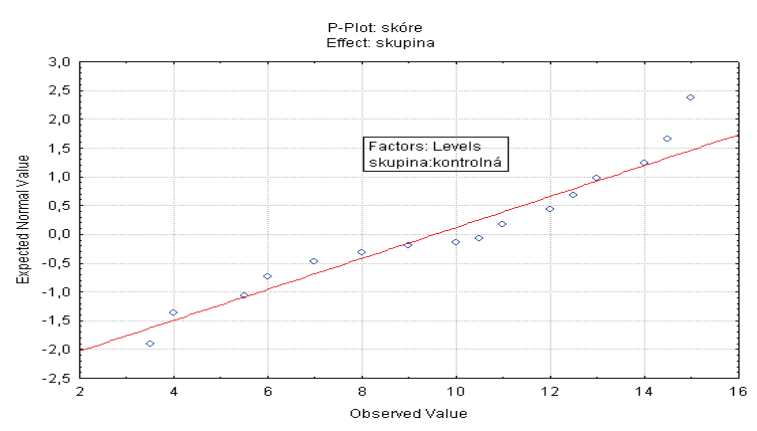

Graf 3: Vyhodnotenie normality náhodných chýb - graf normality reziduí v kontrolnej skupine. 


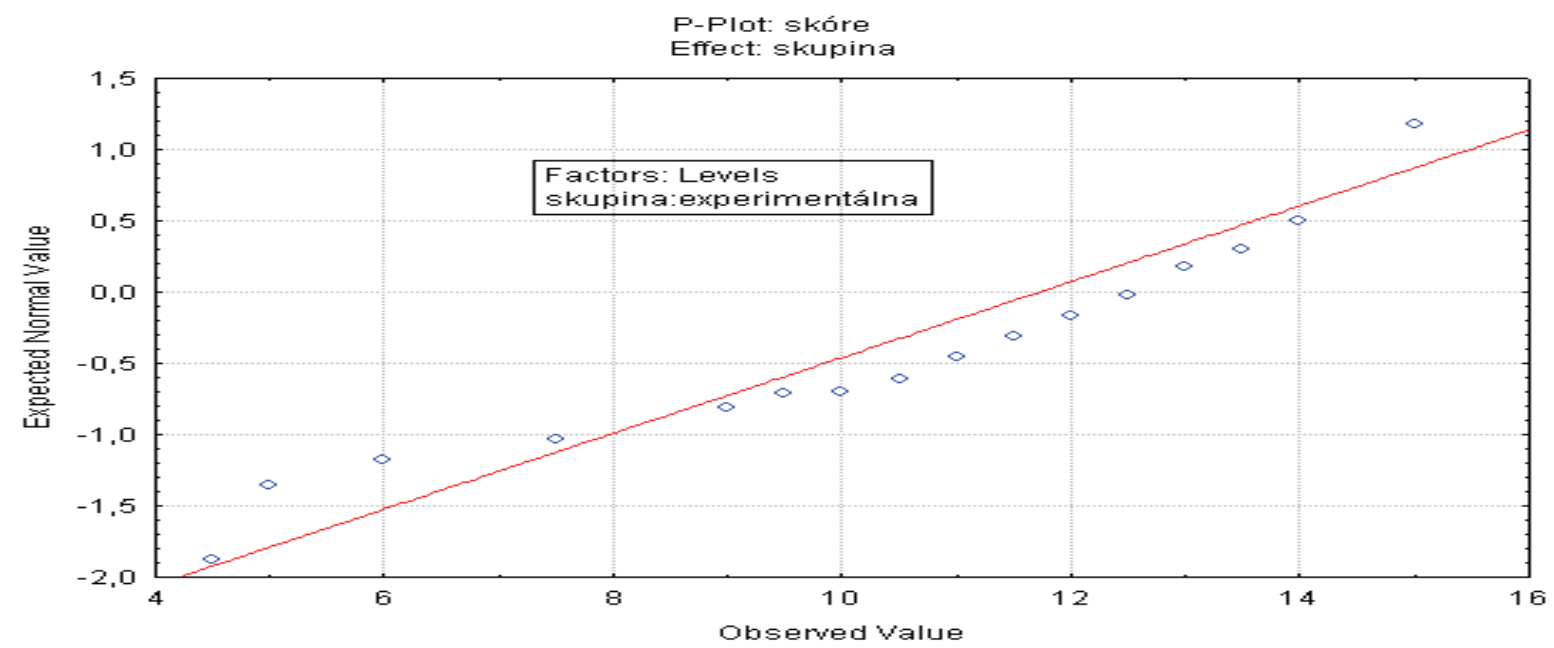

Graf 4: Vyhodnotenie normality náhodných chýb - graf normality rezíduí v experimentálnej skupine.

Tabul'ka 5: Levenov F-test.

\begin{tabular}{|l|c|c|c|c|}
\hline $\begin{array}{l}\text { Levene's } \\
\text { test }\end{array}$ & $\begin{array}{c}\text { MS } \\
\text { Effect }\end{array}$ & $\begin{array}{c}\text { MS } \\
\text { Error }\end{array}$ & F & p \\
\hline Skóre & 30,62752 & 3,094280 & 9,898111 & 0,001737 \\
\hline
\end{tabular}

Tabul'ka 6: Javová analýza úloh DT 1.

\begin{tabular}{|c|c|c|c|c|c|c|c|c|c|c|c|c|}
\hline Č́slo úlohy & $\mathbf{1}$ & $\mathbf{2}$ & $\mathbf{3}$ & $\mathbf{4}$ & $\mathbf{5}$ & $\mathbf{6}$ & $\mathbf{7}$ & $\mathbf{8}$ & $\mathbf{9}$ & $\mathbf{1 0}$ & $\begin{array}{c}\text { DT } \\
\text { spolu }\end{array}$ & $\begin{array}{c}\text { Vážené } \\
\text { skóre P }\end{array}$ \\
\hline Max. počet bodov & 1 & 1 & 2 & 1 & 1 & 2 & 1 & 2 & 3 & 1 & $\mathbf{1 5}$ & \\
\hline$\Sigma$ & 551 & 402 & 822 & 526 & 501 & 612 & 542 & 812 & 1021 & 572 & 6361 & \\
\hline $\mathbf{p} \mathbf{i}, \mathbf{j}$ & 91,8 & 67,0 & 68,5 & 87,6 & 83,5 & 51,0 & 90,3 & 67,6 & 56,7 & 95,3 & & $\mathbf{7 5 , 9} \%$ \\
\hline
\end{tabular}

$\mathbf{P}_{\mathrm{i}, \mathrm{j}}$ - percentuálna úspešnost’ riešenia $\mathbf{j}$-tej úlohy DT1 i-tým žiakom

Tabul'ka 7: Javová analýza úloh DT 1 v kontrolnej skupine.

\begin{tabular}{|c|c|c|c|c|c|c|}
\hline & zapamätanie & $\begin{array}{c}\text { porozumenie } \\
\mathbf{2 , 3 , 5 , 8}\end{array}$ & $\begin{array}{c}\text { špecifický } \\
\text { transfer 6 }\end{array}$ & $\begin{array}{c}\text { nešpecifický } \\
\text { transfer 9 }\end{array}$ & DT spolu & $\begin{array}{c}\text { Vážené skóre } \\
\boldsymbol{P}\end{array}$ \\
\hline $\begin{array}{c}\text { Max. počet } \\
\text { bodov }\end{array}$ & 4 & 6 & 2 & 3 & $\mathbf{1 5}$ & \\
\hline$\Sigma$ & 882 & 1112 & 298 & 577 & 2869 & \\
\hline $\mathbf{p} \mathbf{i}, \mathbf{j}$ & 73,5 & 61,7 & 49,6 & 64,1 & & $\mathbf{6 2 , 2} \%$ \\
\hline
\end{tabular}

$\mathbf{P}_{\mathrm{i}, \mathrm{j}}$ - percentuálna úspešnost’ riešenia $\mathbf{j}$-tej úlohy DT1 i-tým žiakom

Tabul'ka 8: Javová analýza úloh DT 1 v experimentálnej skupine.

\begin{tabular}{|c|c|c|c|c|c|c|}
\hline Č́slo úlohy & $\begin{array}{c}\text { zapamätanie } \\
\mathbf{1 , 4 , 7 , 1 0}\end{array}$ & $\begin{array}{c}\text { porozumenie } \\
\mathbf{2 , 3 , 5 , 8}\end{array}$ & $\begin{array}{c}\text { špecifický } \\
\text { transfer 6 }\end{array}$ & $\begin{array}{c}\text { něspecifický } \\
\text { transfer }\end{array}$ & DT spolu & $\begin{array}{c}\text { Vážené skóre } \\
\boldsymbol{P}\end{array}$ \\
\hline $\begin{array}{c}\text { Max. počet } \\
\text { bodov }\end{array}$ & 4 & 6 & 2 & 3 & $\mathbf{1 5}$ & \\
\hline$\Sigma$ & 994 & 1328 & 481 & 689 & 3492 & \\
\hline p i,j & 82,8 & 73,7 & 80,1 & 76,5 & & $\mathbf{7 8 , 2} \%$ \\
\hline
\end{tabular}

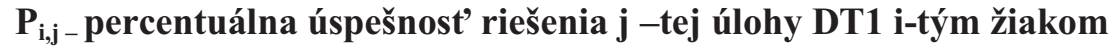


Tabul'ka 9: Kruskal-Wallis teat.

\section{Kruskal-Wallis test}

Variables: A, B. Groups A - kontrolná skupina, Groups B - experimentálna skupina (úroveň zapamätania)

Groups $=2$

$\mathrm{df}=1$

Total observations $=600$

$\mathrm{H}=27,208996$

$\mathrm{P}<0,0001$

Kruskal-Wallis: all pairwise comparisons (Dwass-Steel-Chritchlow-Fligner)

Critical q (range) $=2,771808$
A vs. B
significant
$(|7,864131|>2,771808)$
$P<0,0001$

Kruskal-Wallis: all pairwise comparisons (Conover-Inman)

Critical t (598 df) $=1,963939$

$\mathrm{A}$ and $\mathrm{B}$

significant

$(73,83>27,181452)$

$\mathrm{P}<0,0001$

Tabul'ka 10: Kruskal-Wallis test.

\section{Kruskal-Wallis test}

Variables: A, B. Groups A - kontrolná skupina, Groups B - experimentálna skupina (úroveň porozumenie)

Groups $=2$

$\mathrm{df}=1$

Total observations $=600$

$\mathrm{H}=31,137306$

$\mathrm{P}<0,0001$

Kruskal-Wallis: all pairwise comparisons (Dwass-Steel-Chritchlow-Fligner)

Critical q (range) $=2,771808$

A vs. B

significant

$(|8,032412|>2,771808)$

$\mathrm{P}<0,0001$

Kruskal-Wallis: all pairwise comparisons (Conover-Inman)

Critical t (598 df) $=1,963939$

$\mathrm{A}$ and $\mathrm{B}$

$(78,98>27,08792)$

significant

$P<0,0001$

Tabul'ka 11: Kruskal-Wallis test.

\section{Kruskal-Wallis test}

Variables: A, B. Groups A - kontrolná skupina, Groups B - experimentálna skupina (úroveň špecifický transfer).

Groups $=2$

$\mathrm{df}=1$

Total observations $=600$

$H=108,384384$

$P<0,0001$ 
Kruskal-Wallis: all pairwise comparisons (Dwass-Steel-Chritchlow-Fligner)

Critical q (range) $=2,771808$

A vs. B

significant

$(|15,469943|>2,771808)$

$P<0,0001$

Kruskal-Wallis: all pairwise comparisons (Conover-Inman)

Critical t (598 df) $=1,963939$

$\begin{array}{ll}A \text { and } B & \text { significant } \\ (147,353333>25,1782) & P<0,0001\end{array}$

Tabul'ka 12: Kruskal-Wallis test.

\section{Kruskal-Wallis test}

Variables: A, B. Groups A - kontrolná skupina, Groups B - experimentálna skupina (úroveň nešpecifický transfer).

Groups $=2$

$\mathrm{df}=1$

Total observations $=600$

$H=29,062556$

$\mathrm{P}<0,0001$

Kruskal-Wallis: all pairwise comparisons (Dwass-Steel-Chritchlow-Fligner)

Critical q (range) $=2,771808$

A vs. B

$(|8,070786|>2,771808)$

significant

$P<0,0001$

\section{Kruskal-Wallis: all pairwise comparisons (Conover-Inman)}

Critical t (598 df) $=1,963939$
$A$ and $B$
$(76,303333>27,137359)$
significant
$P<0,0001$

Zaujímalo nás, aké výkony žiaci dosahujú pri riešení didaktického testu. Správnym riešením didaktického testu pre 7. ročník mohol žiak získat' maximálne 15 bodov hrubého skóre (hs) v 7. ročníku. Už z popisnej štatistiky (Tabul'ka $1,2,3)$ je zrejme, že žiaci 7 . ročníka experimentálnej skupiny zvládli učivo úspešnejšie ako žiaci kontrolnej skupiny. Vypočítaný aritmetický priemer a smerodajná odchýlka boli vypočítané na intervale spol'ahlivosti: dolný interval: $-95 \%$, horný interval $+95 \%$.

Z grafu 1 je možné taktiež vidiet', že dosiahnuté výsledky vexperimentálnej skupine boli lepšie ako v kontrolnej skupine. Vypočítaný aritmetický priemer pre experimentálnu skupinu je $\mathrm{z}$ intervalu spol'ahlivosti merania od 11,26 po 12,02 a pre kontrolnú skupinu je $\mathrm{z}$ intervalu spol'ahlivosti merania od 9,17 po 9,96 .

Variačné rozpätie je určené minimálnou hodnotou 3,5 a maximálnou 15. Zistili sme, že dosiahnuté výsledky medzi žiakmi sú rozdielne. $\mathrm{Z}$ grafu 2 je vidiet', že stredná hodnota súboru pri kontrolnej skupine je rovná 11 a pri experimentálnej skupine je rovná 12,5. Kvartilové rozpätie reprezentuje oblast' stredných 50 percent hodnôt premenných, t.j u kontrolnej skupiny od 6 do 12,5 a u experimentálnej skupiny od 10,5 do 14 .

Či sú tieto výsledky štatisticky významne, sme zist'ovali analýzou hodnôt. Aby sme mohli vybrat' správnu analýzu hodnôt, najprv sme museli skúmat' predpoklad o normálnom rozdelení pravdepodobnosti náhodných chýb. Predpoklad o normálnom rozdelení pravdepodobnosti náhodných chýb sme skúmali pomocou histogramu a taktiež porovnaním rozptylov základných súborov. Obidva grafy (Graf 3, 4) nie sú jednoznačne symetrické a taktiež vypočítane rozptyly (variances) nie sú rovnaké (Tabul'ka 5) . Rozptyly oboch súborov sa nerovnajú, lebo $0,05>0,001737$ ( $\alpha>$ p hodnota). 
$\mathrm{Na}$ základe zistených skutočností, sme sa rozhodli použit' neparametrický test Kruskal Wallisov test (Tabul'ka 4).

Nulovú hypotézu zamietame, ak $\mathrm{H} \geq \chi_{1-\alpha(\mathrm{k}-1)}^{2}$ Pre hladinu významnosti $\alpha=0,05$ je oblast' zamietnutia určená hodnotou kvantilu $\chi_{1-\alpha(\mathrm{k}-1)}^{2}=$ $\chi_{0,95(1)}^{2}=3,841$. To znamená, že hodnota testovacej štatistiky sa nachádza v oblasti zamietnutia nulovej hypotézy. Z toho vyplýva záver, že výkony, ktoré dosiahli žiaci kontrolnej a experimentálnej skupiny sú štatisticky rozdielne. Taktiež vypočítaná $\mathrm{p}$ hodnota je príliš malá hodnota, nulovú hypotézu zamietame. Záverom môžeme konštatovat', že hypotéza $\mathrm{H}_{1}$ a $\mathrm{H}_{2}$ sa potvrdila (Tabul'ka 6).

Určili sme javovú analýzu úloh didaktického testu. Na základe javovej analýzy úloh didaktického testu sme zistili úspešnost' riešenia jednotlivých prvkov učiva obsiahnutých v didaktickom teste. Úlohy v didaktickom teste boli vážené, vypočítali sme celkové vážené skóre, ktoré je váženým priemerom úspešnosti riešenia úloh didaktického testu. $\mathrm{V}$ prípade nášho výstupného didaktického testu si žiaci nedostatočne osvojili učivo obsiahnuté v úlohách 6 a 9 (Tabul'ka 6), ktoré žiaci vyriešili s priemernou úspešnost'ou menšou ako $60 \%$. Ide o úlohy, ktorých riešenie si vyžaduje správnu aplikáciu teoretických informácií a poznatkov v typických školských a problémových úlohách. $\mathrm{Z}$ porovnania úspešnosti riešenia úloh u žiakov 7 . ročníka v kontrolnej a experimentálnej skupine vyplýva, že vo všetkých štyroch úrovniach učenia podl'a Niemierkovej taxonómie vzdelávacích ciel'ov žiaci experimentálnych skupín boli úspešnejší v riešení úloh oproti žiakom kontrolných skupín (Tabul'ka 7, 8). Či boli rozdiely $v$ jednotlivých úrovniach učenia aj štatisticky významné medzi žiakmi kontrolnej a experimentálnej skupiny v 7. ročníku, zist'ovali sme Kruskal - Wallisovym testom. Výsledky uvádzame v Tabul'ke 9 až 12. Zistili sme, že vypočítaná p hodnota je príliš malá hodnota, to znamená, že hypotézy $\boldsymbol{H}_{2.1}-\boldsymbol{H}_{2.4}$ sa potvrdili na hladine významnosti $\alpha=0,05$.

\section{Záver}

Domnievame sa, že sa nám podarilo dokázat', že aplikácia hypertextového učebného textu do edukačného procesu je opodstatnená a prináša zefektívnenie výsledkov výučby.

Rozbor problematiky súvisiaci s vyučovaním technickej výchovy na II. stupni základnej školy nemožno pokladat' za úplný a uzavretý, lebo sa jedná len o 7. ročník. Problematika a jej navrhnuté riešenie, by mali byt' po dôkladnej analýze rozšírené aj na d'alšie ročníky. Ak chceme dobre vychovávat' mladú generáciu pre náročnejšie podmienky, musíme jej už od detstva vštepovat' technickú kultúru a to v primeraných podmienkach. A práve nami navrhnutý, vytvorený a overený hypertextový učebný text by mal tomu napomôct'.

\section{Literatúra}

[1] ASKERUD, P., 1998: A guide to sustainable book provision. Paris: UNESCO.

[2] ĎURIŠ, M. - PAVLOVKIN, J., 2003: Spotrebiče v domácnosti. Banská Bystrica: FPV UMB, 89 s. ISBN 80-8055-761-6.

[3] CHAJDIAK, J. - RUBLÍKOVÁ, E. GUDÁBA, M., 1994: Štatistické metódy v praxi. Bratislava: STATIS, 158 s. ISBN 80-85659-02-6. [4] KOŽUCHOVÁ, M., 1993: Rozvoj technickej tvorivosti. Bratislava: Univerzita Komenského. ISBN 80-223-1393-9.

[5] OECD, 1999: Organisation for Economic Cooperation and Development. Classifying Educational Programmes: Manual for ISCED-97 Implementation in OECD Countries. ed. Paris.

[6] TORRANCE, P. I., 1964: Guiding Creative Talent. Englewood Clifs. New Jersey: Printice Hall publishing Co. ISBN 40-7456-12-0.

PaedDr. L’ubomír Žáčok, PhD.

Katedra techniky a technológií

Fakulta prírodných vied UMB

Tajovského 40

97401 Banská Bystrica, SR

tel.: +421 484467216

E-mail: zacok@fpv.umb.sk www.fpv.um 